\title{
Analisis Efektivitas Distribusi Zakat Produktif \\ Dalam Meningkatkan Kesejahteraan Mustahik \\ (Studi Kantor Cabang Rumah Zakat Sumatera Utara)
}

\author{
Mulkan Syahriza \\ STAI Jamiatut Tarbiyah Lhoksukon \\ azzaimulkan@gmail.com \\ Pangeran Harahap \\ Pascasarjana UIN Sumatera Utara Medan \\ pangeranharahap@uinsu.ac.id \\ Zainul Fuad \\ Pascasarjana UIN Sumatera Utara Medan \\ zainulfuad@uinsu.ac.id
}

\begin{abstract}
This study aims to explain how the distribution of productive zakat in the Rumah Zakat North Sumatra and how the effectiveness of productive zakat distribution in improving the welfare of mustahik in the Rumah Zakat North Sumatra. This study uses a qualitative approach with a type of descriptive method, which is a problem that guides researchers to explore and photograph situations that will be thoroughly investigated, broadly and deeply. Data collection techniques with field research, while the tools used are observation, interviews and documentation. Data analysis used is descriptive qualitative analysis. The results of this study inform that in distributing productive zakat funds, Rumah Zakat is in accordance with Law No. 23 of 2011 concerning Management of Zakat. The distribution of productive zakat carried out by the Rumah Zakat North Sumatra through the Senyum Mandiri Program to mustahik in Medan Helvetia Subdistrict has been effective, because it can improve the welfare of mustahik, this is evidenced by the income of eight of thirteen mustahik people in total, five people whose income is fixed and four out of eight people whose income has increased has reached the level of muzaki.
\end{abstract}

Keywords: Effectiveness, Distribution, Productive Zakat, Welfare, Mustahik

\begin{abstract}
Abstrak
Penelitian ini bertujuan untuk menjelaskan bagaimana pendistribusian zakat produktif di Rumah Zakat Sumatera Utara dan bagaimana efektivitas distribusi zakat produktif dalam meningkatkan kesejahteraan mustahik di Rumah Zakat Sumatera Utara. Penelitian ini menggunakan pendekatan kualitatif dengan jenis metode deskriptif, yaitu masalah yang memandu peneliti untuk mengeksplorasi dan mamotret situasi yang akan diteliti secara menyeluruh, luas dan mendalam. Teknik pengumpulan data dengan penelitian lapangan (field research), sedangkan alat yang digunakan adalah observasi, wawancara dan dokumentasi. Analisis data yang digunakan adalah analisis kualitatif deskriptif. Hasil penelitian ini menginformasikan bahwa dalam mendistribusikan dana zakat produktif, Rumah Zakat telah sesuai dengan Undang-undang No. 23 tahun 2011 tentang Pengelolaan Zakat. Distribusi zakat produktif yang dilaksanakan oleh Rumah Zakat Sumatera Utara melalui Program Senyum Mandiri kepada mustahik di Kecamatan Medan Helvetia sudah efektif, karena dapat meningkatkan kesejahteraan mustahik, ini dibuktikan dengan meningkatnya pendapatan delapan
\end{abstract}


dari tiga belas orang mustahik secara keseluruhan, lima orang yang pendapatannya tetap dan empat dari delapan orang yang pendapatannya meningkat telah mencapai tingkat muzaki.

Kata Kunci: Efektivitas, Pendistribusian, Zakat Produktif, Kesejahteraan, Mustahik

\section{Pendahuluan}

Pendistribusian harta bagi orang yang mampu kepada orang yang membutuhkan dalam Islam diantaranya ialah melalui zakat, infak dan sedekah. Sistem zakat, infak dan sedekah sudah diatur secara jelas dalam ketentuan yang dijelaskan Alquran dan Hadits. Ketentuan ini sudah lengkap dan komprehensif yang dapat dipakai di segala zaman dan tidak terikat waktu. Misalnya zakat, Ilmu fikih telah menetapkan secara jelas ketentuan tentang jenis-jenis harta zakat, nis\{ab, h\{aul, cara kerja, amil, baitul mal, mustahik dan lainnya.

Pada prinsipnya, walaupun kewajiban zakat lebih terkait pada masingmasing pribadi Muslim tetapi pada pelaksanaannya bukanlah semata-mata diserahkan pada kesadaran muzaki, namun hal ini merupakan persoalan kemasyarakatan. Oleh karena itu diperlukan sebuah lembaga atau badan untuk mengatur pelaksanaannya, meliputi: mengkoordinir, mengumpulkan harta zakat dari muzaki (pemberi zakat) dan mendistribusikan dana zakat yang terkumpul kepada mereka yang berhak menerimanya.

Di antara tujuan didirikannya lembaga pendistribusian zakat ialah agar bagi muzaki (pembayar zakat) dan mustahik (yang berhak menerima zakat) lebih jelas dan terstruktur pengelolaannya, karena yang terpenting dari zakat adalah bagaimana mengelolanya. Oleh sebab itu amil zakat haruslah memahami secara profesional bagaimana sistem pengelolaan zakat sebagai unsur yang sangat penting dan strategis dalam melaksanakan tugasnya, bahkan dalam Alquran amil ditempatkan dalam urutan sebagai golongan penerima zakat meskipun tidak tergolong orang miskin. ${ }^{1}$ Dari sisi inilah terlihat betapa pentingnya posisi amil.

Adapun yang perlu dijadikan pedoman sebagai pelengkap bagi para amil dalam mengelola zakat sebagaimana yang terdapat dalam surat at-Taubah ayat 103.

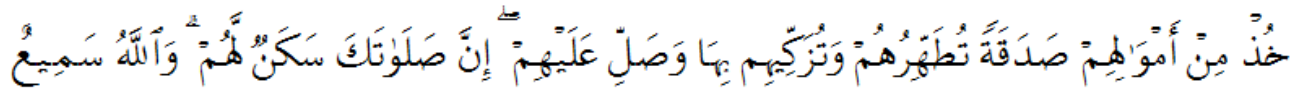


Artinya: "Ambillah zakat dari sebagian, harta mereka dengan zakat itu kamu membersihkan dan mensucikan mereka dan mendoalah untuk mereka. Sesungguhnya do'a kamu itu menjadi ketentraman jiwa bagi mereka dan Allah Maha Mendengar lagi Maha Mengetahui.", 2

Secara mendasar dalam firman Allah SWT Surat at-Taubah ayat 103 telah disebutkan beberapa hal yang perlu diperhatikan oleh para amil atau pengelola zakat, di antaranya "Ambillah dari harta mereka sedekah (zakat)", dari kata-kata ini dapat ditarik kesimpulan adanya Al-Mudharabah (inisiatif) manajemen yang berarti amil tidak sekedar menunggu datangnya zakat tersebut, akan tetapi amil haruslah memperhatikan sikap amil yang dituangkan dalam bentuk perencanaan, srategi dan pengelolaan yang baik.

Sebagaimana yang telah dijelaskan dalam Undang-Undang Republik Indonesia Nomor 23 tahun 2011 tentang pengelolaan zakat pasal 25 menjelaskan bahwa zakat wajib didistribusikan kepada mustahik sesuai dengan ketentuan syariat Islam dan pasal 27 zakat dapat didayagunakan untuk usaha produktif dalam rangka penanganan fakir miskin dan peningkatan kualitas umat. ${ }^{3}$

Dengan demikian, dapat dipahami bahwa pendistribusian zakat sebaiknya diprioritaskan untuk membangun usaha produktif bagi penerima zakat agar mampu mendatangkan pendapatan bagi mustahik dan bahkan dapat menyerap tenaga kerja. Dengan kata lain pendistribusian zakat haruslah ada perubahan dari pola konsumtif menuju pola produktif. Karena sebagaimana yang diketahui bahwa secara umum pendistribusian zakat masih banyak dalam bentuk konsumtif. Hal ini dimaksudkan untuk dapat meningkatkan kemampuan fakir miskin dalam menciptakan pendapatan dan mengeluarkan dirinya dari perangkap kemiskinan.

Di samping itu pola pendistribusian zakat untuk usaha produktif sangat efektif untuk memproyeksikan perubahan seorang mustahik menjadi muzaki, sedangkan pola menginvestasikan dana zakat diharapkan dapat efektif memfungsikan sistem zakat sebagai suatu bentuk jaminan sosial masyarakat muslim, terutama untuk kelompok miskin/defisit atau dengan bahasa lain sekuritisasi sosial. ${ }^{4}$ Untuk peningkatan dan efektivitas pendistribusian zakat, maka diperlukan lembaga yang efektif dalam mendistribusikannya. Dalam aspek pendistribusian dana zakat, sejauh ini terdapat dua pola penyaluran zakat; yaitu pola tradisional (konsumtif) dan pola penyaluran produktif (pemberdayaan 
ekonomi). Pembagian zakat dewasa ini umumnya dilakukan oleh Lembaga Amil Zakat adalah dengan cara konsumtif. Padahal metode ini kurang menyentuh pada persoalan yang dihadapi para mustahik, karena hanya membantu kesulitan mereka sesaat. Maka dari itu, Pemerintah memberi peluang bagi BAZ dan LAZ, untuk membantu mengupayakan dalam hal mensejahterakan fakir dan miskin (mustahik) agar taraf perekonomiannya meningkat, yaitu dengan mendayagunakan hasil zakat secara produktif, sebagaimana tersebut dalam Undang-undang No. 23 tahun 2011 tentang pengelolaan zakat. Dalam rangka menjalankan hal tersebut, sekarang ini telah banyak tumbuh lembaga amil zakat yang mencoba memberikan dananya secara produktif dengan tujuan untuk mengubah keadaan penerima dari kategori mustahik menjadi muzaki, diantaranya adalah Lembaga Amil Zakat Rumah Zakat kantor cabang Sumatera Utara.

Rumah zakat merupakan sebuah lembaga swadaya masyarakat yang memfokuskan pada pengelolaan zakat, infaq dan shadaqah secara professional dengan menitikberatkan pada program pendidikan, kesehatan, pembinaan komunitas dan pemberdayaan ekonomi sebagai program penyaluran unggulan. Legalitas untuk melakukan ekspansi semakin kuat ketika lembaga ini telah mendapat sertifikasi pengukuhan sebagai Lembaga Amil Zakat Nasional berdasarkan SK Menteri Agama RI No. 157 pada tanggal 18 Maret 2003. Perkembangan cabang pun tumbuh secara cepat. Hingga awal 2006 Rumah Zakat telah memiliki kantor pusat di Bandung dan 28 titik titik kantor pelayanan di 12 provinsi utama di Indonesia, salah satunya provinsi Sumatera Utara. ${ }^{5}$

Semestinya zakat dapat terdistribusi secara efektif dengan adanya sasaran dan penggunaan yang tepat oleh mustahik. Namun kenyataannya berdasarkan informasi awal yang diperoleh oleh peneliti bahwa penyaluran zakat yang dilakukan oleh Rumah Zakat Sumatera Utara memiliki cara sendiri dalam pendistribusian dana zakat, yaitu melalui beberapa program yang salah satunya adalah program Senyum Mandiri. Senyum mandiri merupakan salah satu program Rumah Zakat yang berupaya untuk memandirikan masyarakat melalui serangkaian proses pemberdayaan masyarakat dengan sistem distribusi zakat produktif. Program senyum mandiri ini dilaksanakan di beberapa lokasi, salah satunya adalah Kelurahan Dwikora Kecamatan Medan Helvetia. Kelurahan Dwikora ini merupakan lokasi yang memiliki waktu proses program berjalan yang 
terlama dari lokasi lainnya, yaitu program sudah berjalan selama hampir 3 tahun lebih.

Dalam melaksanakan program pendistribusian zakat produktif banyak terjadi problem di lapangan yang menyebabkan pendayagunaan zakat di bidang ekonomi menjadi risiko kegagalan yang tinggi; diantaranya kegagalan terjadi karena faktor usahanya sendiri, misalnya kelemahan aspek produksi dan pemasaran, faktor eksternal seperti cuaca dan hilangnya tempat usaha serta yang paling banyak adalah faktor internal mustahik itu sendiri, seperti: rendahnya motivasi berusaha, ketidakdisiplinan dalam penggunaan dana dan keinginan untuk mendapatkan hasil secara cepat (instan).

Selain faktor dari mustahik yang berdampak pada berhasil tidaknya program zakat produktif, faktor yang berasal dari lembaga zakat juga memberi dampak pada keberhasilan pencapaian tujuan pendayagunaan zakat produktif, diantaranya; proses perencanaan program yang belum matang, SDM pendamping yang kurang handal dan tidak adanya alat ukur keberhasilan program yang tepat. Maka dari itu sangatlah penting untuk mengetahui keektifan pendistribusian zakat produktif di Rumah Zakat Sumatera Utara agar dilakukan suatu analisis pelaksanaannya.

Karena prinsip efektivitas sebagaimana bagian dari manajemen zakat merupakan asas terpenting yang harus dilaksanakan oleh berbagai lembaga tidak terkecuali lembaga non profit seperti lembaga zakat agar dapat mengetahui sejauh mana fungsi dari program yang ada bermanfaat bagi masyarakat. Prinsip ini juga sangat dibutuhkan sebagai upaya evaluasi dalam rangka mengotimalisasi peranan lembaga zakat. Hal ini semata-mata agar kinerja lembaga zakat tetap berjalan secara profesional dan tetap menjunjung tinggi nilai-nilai Islam.

Seperti yang disampaikan oleh Didin Hafidhuddin, keberhasilan sebuah lembaga zakat adalah bukan ditentukan oleh besarnya dana zakat yang dihimpun atau didayagunakan, melainkan pada sejauh mana para mustahik (yang mendapatkan zakat produktif) dapat meningkatkan kegiatan usaha ataupun pekerjaannya. ${ }^{6}$ Oleh karena itu, untuk mengoptimalkan fungsi zakat khususnya pada aspek pendistribusian dan pendayagunaan zakat produktif dalam menjalankan tugas sebagai amil zakat juga dengan berlandaskan undang-undang pengelolaan zakat no. 23 tahun 2011 dibutuhkan ukuran efektivitas pendistribusian zakat produktif dalam meningkatkan kesejahteraan mustahik, maka penulis terdorong untuk melakukan penelitian lebih lanjut terkait efektivitas 
distribusi zakat produktif dalam meningkatkan kesejahteraan mustahik yang dilakukan oleh Rumah Zakat.

\section{Kajian Teoritis}

\section{Efektivitas}

Menurut Kamus Besar Bahasa Indonesia, kata efektif berarti dapat membuahkan hasil, mulai berlaku, ada pengaruh/akibat/efeknya. Efektivitas bisa juga diartikan sebagai pengukuran keberhasilan dalam pencapaian tujuan-tujuan. ${ }^{7}$ Menurut Harbani Pasolong efektivitas pada dasarnya berasal dari kata "efek" dan digunakan istilah ini sebagai hubungan sebab akibat. Efektivitas dapat dipandang sebagai suatu sebab dari variabel lain. Efektivitas berarti bahwa tujuan yang telah direncanakan sebelumnya dapat tercapai atau dengan kata lain sasaran tercapai karena adanya proses kegiatan. ${ }^{8}$

Pengertian efektivitas menurut Agung Kurniawan adalah kemampuan melaksanakan tugas, fungsi (operasi kegiatan program atau misi) daripada suatu organisasi atau sejenisnya yang tidak adanya tekanan atau ketegangan diantara pelaksanaannya. ${ }^{9}$ Menurut Gibson Efektivitas adalah pencapaian tujuan dan sasaran yang telah disepakati untuk mencapai tujuan bersama. Tingkat tujuan dan sasaran itu menunjukkan tingkat efektivitas. Tercapainya tujuan dan sasaran itu akan ditentukan oleh tingkat pengorbanan yang telah dilakukan. ${ }^{10}$

Menurut Sondang P. Siagian efektivitas adalah pemanfaatan sumber daya, sarana dan prasarana dalam jumlah tertentu yang secara sadar ditetapkan sebelumnya untuk menghasilkan sejumlah barang atas jasa kegiatan yang dijalankannya. Efektivitas menunjukkan keberhasilan dari segi tercapai tidaknya sasaran yang telah ditetapkan. Jika hasil kegiatan semakin mendekati sasaran berarti makin tinggi efektivitasnya. ${ }^{11}$ Menurut Martani dan Lubis efektivitas merupakan unsur pokok aktivitas untuk mencapai tujuan atau sasaran yang ditentukan sebelumnya. Dengan kata lain suatu organisasi disebut efektif apabila tercapai tujuan atau sasaran yang telah ditentukan sebelumnya. ${ }^{12}$

Dari beberapa pengertian efektivitas diatas maka dapat dipahami bahwa yang menjadi indikator efektivitas ialah tercapainya tujuan dari sebuah lembaga, maka kembali ke tujuan dari distribusi zakat produktif yang dilaksanakan oleh Rumah Zakat ialah agar dapat merubah mustahik zakat muzaki, tetapi pokok dasar dari makna senyum mandiri ialah agar para dhuafa bisa tersenyum dengan 
kemandirian dari usahanya. Maka bisa diambil kesimpulan bahwa program senyum mandiri ini dilaksanakan untuk mengupayakan mustahik menjadi muzaki, tetapi jika tidak menjadi muzaki, maka setidaknya para mustahik zakat mampu mandiri secara ekonominya sehingga bisa dikatakan program senyum mandiri yang dilaksanakan oleh Rumah Zakat sudah efektif.

\section{Pendistrisbusian Zakat}

Pendistribusian adalah tata cara atau tindakan penyaluran barang atau jasa ke pihak lain dengan tujuan tertentu. ${ }^{13}$ Jadi, pendistribusian zakat adalah penyaluran zakat kepada orang yang berhak menerima (mustahik) baik secara konsumtif ataupun produktif dengan tujuan agar kesejahteraan mustahik dapat meningkat. Sasaran mustahik zakat sudah ditentukan sebagimana disebutkan dalam surat atTaubah ayat 60 yaitu delapan golongan. Dari ayat tersebut cukup jelas bahwa pendistribusian zakat harus sampai kepada delapan golongan yang telah disebutkan, walaupun dalam perkembangannya mengalami perluasan makna karena menyesuaikan dengan perkembangan situasi dan kondisi modern.

Model pendistribusian harta zakat oleh muzaki ada dua cara yaitu dapat dilakukan secara langsung kepada mustahik atau lewat lembaga zakat yang nantinya akan disalurkan kepada mustahik. ${ }^{14}$ Distribusi zakat terkadang hanya bersirkulasi pada suatu tempat tertentu, ketika zakat tidak dikelola secara keseimbangan dan diberikan langsung oleh si pemberi zakat (muzaki) kepada mustahik. Hal ini salah satu faktor penyebabnya karena kurang adanya lembaga zakat yang profesional, yang menyampaikan dana zakat tersebut kepada umat yang membutuhkan juga berimplikasi pada peningkatan kesejahteraan masyarakat. $^{15}$

Untuk mencapai hasil yang maksimal, efektif dan efisien serta tercapainya tujuan dan sasaran zakat, maka pendayagunaan alokasi dana zakat dapat digolongkan kedalam empat katagori, sebagai berikut:

a. Bersifat konsumtif tradisional yaitu zakat dibagikan kepada mustahik untuk dimanfaatkan secara langsung, seperti zakat fitrah yang diberikan kepada fakir miskin untuk memenuhi kebutuhan sehari-hari atau zakat harta yang dibagikan kepada para korban bencana alam. 
b. Penyaluran bersifat konsumtif kreatif yaitu zakat diwujudkan dalam bentuk lain dari barangnya semula, seperti diberikan dalam bentuk alat-alat sekolah atau beasiswa.

c. Penyaluran dalam bentuk produktif tradisional yaitu zakat yang diberikan dalam bentuk barang produktif seperti kambing, sapi, alat cukur, dan sebagainya. Pemberian dalam bentuk alat produksi tersebut diharapkan dapat menciptakan suatu usaha yang membuka lapangan kerja bagi fakir miskin.

d. Penyaluran dalam bentuk produktif kreatif yaitu zakat diberikan dalam bentuk pemodalan baik untuk membangun proyek sosial atau menambah modal pedagang atau pengusaha kecil. ${ }^{16}$

\section{Zakat Produktif}

Definisi zakat produktif akan menjadi lebih mudah dipahami jika diartikan berdasarkan suku kata yang membentuknya. Ditinjau dari segi bahasa, dalam Bahasa Arab, kata zakat merupakan kata dasar (mașdar) dari "zakā (زكا)" yang berarti suci, berkah, tumbuh, kebaikan dan terpuji. ${ }^{17}$

Secara terminologi, dalam kitab Syafiiyah, Mugniy al-Muhtāj disebutkan definisi zakat adalah nama bagi sejumlah harta tertentu untuk dialokasikan dan diberikan kepada orang-orang tertentu setelah memenuhi syarat tertentu pula. ${ }^{18}$ Menurut Saparuddin Zakat adalah harta yang wajib dikeluarkan oleh muzaki sesuai dengan ketentuan syariah untuk diberikan kepada yang berhak menerimanya (mustahik). ${ }^{19}$

Dari definisi diatas maka dapat disimpulkan bahwa zakat adalah pungutan wajib atas individu yang memiliki harta wajib zakat yang melebihi nis $\{a b$ (muzaki), dan didistribusikan kepada penerima zakat (mustahik) delapan golongan yaitu: fakir, miskin, fî sabîlillâh, ibnu sabîl, amil, gharimîn, riqab dan muallaf. dan harta yang dikeluarkan zakatnya akan menjadi berkah, tumbuh, berkembang dan bertambah serta suci dan baik.

Sedangkan kata produktif berasal dari bahasa inggris yaitu "productive" yang berarti banyak menghasilkan, memberikan banyak hasil, banyak menghasilkan barang-barang berharga, yang mempunyai hasil baik. Productivity yang berarti daya produksi. ${ }^{20}$ Secara umum kata produktif "productive" berarti banyak menghasilkan karya atau barang. Dalam Kamus Besar Bahasa Indonesia kata produktif berarti banyak mendatangkan hasil. ${ }^{21}$ Dan dalam kamus besar ilmu 
pengetahun kata produktif berarti banyak menghasilkan, memberikan banyak hasil. ${ }^{22}$ Pengertian produktif dalam hal ini adalah kata yang disifati yaitu zakat. Sehingga zakat produktif yang artinya zakat dimana dalam pendistribusiannya bersifat yang merupakan lawan dari konsumtif.

Dengan demikian dapat disimpulkan bahwa zakat produktif adalah pemberian zakat yang dapat membuat para penerimanya menghasilkan sesuatu secara terus menerus dengan harta zakat yang telah diterimanya. Dimana harta atau dana zakat yang diberikan kepada mustahik tidak dihabiskan, akan tetapi dikembangkan dan digunakan untuk membantu usaha mereka, sehingga dengan usaha tersebut mereka dapat memenuhi kebutuhan hidup secara terus menerus. Yaitu dengan harta zakat itu didayagunakan (dikelola), dikembangkan sedemikian rupa sehingga bisa mendatangkan manfaat yang akan digunakan dalam memenuhi kebutuhan mustahik tersebut dalam jangka panjang, dengan harapan secara bertahap, pada suatu saat tidak lagi masuk dalam kelompok mustahik zakat.

Dalam penyaluran zakat poduktif ada dua macam yaitu zakat produktif tradisional dan produktif kreatif. Zakat produktif tradisional adalah zakat yang diberikan dalam bentuk barang-barang produktif. Misalnya kambing, sapi, mesin jahit, alat-alat pertukangan dan sebagainya. Pemberian zakat dalam bentuk ini akan dapat mendorong orang menciptakan suatu usaha atau memberikan lapangan kerja bagi fakir miskin. Kategori terakhir yaitu zakat produktif kreatif yaitu semua pendayagunaan zakat yang diwujudkan dalam bentuk modal yang dapat dipergunakan untuk membangun suatu proyek sosial maupun untuk membantu atau menambah modal seseorang pedagang atau pengusaha kecil. ${ }^{23}$

Dari pembagian macam-macam zakat produktif diharapkan arah dan kebijaksanaan pengelolaan zakat produktif dapat berhasil sesuai dengan sasaran yang dituju. Adapun maksud arah dan kebijaksanaan pengelolaan zakat adalah segala sesuatu yang berkaitan dengan usaha pemerintah atau pengelola dalam rangka memanfaatkan hasil-hasil pengumpulan zakat kepada sasaran dalam pengertian yang lebih luas sesuai dengan cita dan rasa syara', secara tepat guna, efektif manfaatnya dengan sistem distribusi yang serba guna dan produktif sesuai dengan pesan dan kesan syariat serta tujuan sosial ekonomis dari zakat.

Beberapa ulama modern dan ilmuwan telah menginterpretasikan pendayagunaan zakat dalam perspektif yang lebih luas mencakup edukatif, produktif dan ekonomis. Dalam kehidupan sosial sekarang, pengelolaan dan 
penyaluran zakat untuk penduduk miskin harus mencakup: a) Pembangunan prasarana dan sarana pertanian sebagai tumpuan kesejahteraan ekonomi rakyat, dalam pengertian yang luas; b) Pembangunan sektor industri yang secara langsung berorientasi pada peningkatan kesejahteraan rakyat banyak; c) Penyelenggaraan sentra-sentra pendidikan keterampilan dan kejuruan untuk mengatasi pengangguran; d) Pemberian modal usaha kepada mustahik sebagai langkah awal mendirikan usaha; e) Jaminan hidup orang-orang invalid, jompo, yatim piatu, dan orang-orang yang tidak punya pekerjaan; f) Pengadaan sarana dan prasarana kesehatan bagi setiap warga atau rakyat yang membutuhkan; dan g) Pengadaan sarana dan prasarana yang erat hubungannya dengan usaha menyejahterakan rakyat lapisan bawah. ${ }^{24}$

\section{Metode Penelitian}

Penelitian ini adalah penelitian lapangan (field research) dengan jenis penelitian kualitatif. Penelitian kualitatif bermaksud untuk memahami fenomena yang dialami oleh subjek penelitian misalnya perilaku, persepsi, motivasi, tindakan dan sebagainya digambarkan dengan cara deskriptif dalam bentuk katakata dan bahasa pada suatu konteks khusus yang alamiah dan dengan memanfaatkan berbagai metode ilmiah. ${ }^{25}$ Penelitian ini berusaha mempelajari dan memahami tindakan dan perilaku pengelola dan pengurus Rumah Zakat dalam konteks alaminya tentang pendistribusian Zakat Produktif yang dilaksanakan oleh pengelola Rumah zakat.

Selanjutnya pendekatan yang digunakan oleh peneliti dalam penelitian ini adalah pendekatan kualitatif dengan jenis data metode deskriptif, yaitu metode yang memandu peneliti untuk mengeksplorasi dan atau memotret situasi yang akan diteliti secara menyeluruh, luas dan mendalam. ${ }^{26}$ Penelitian deskriptif yaitu mencatat secara teliti segala gejala-gejala yang dilihat dan didengar dan dibacanya (via wawancara, foto, video, dokumen pribadi, brosur dan lain-lain) dan peneliti juga membandingkan mengkombinasikan dan menarik kesimpulan. ${ }^{27}$

Dalam penelitian ini, peneliti fokus pada penjelasan sistematis yaitu menggambarkan perilaku pengelola atau pengurus Rumah Zakat dalam pendistribusian zakat produktif dengan berpegang pada teori-teori yang telah teruji mengenai efektivitas dan pendistribusian zakat produktif sebagai 
perbandingan. Sumber data yang digunakan berupa data $\operatorname{primer}^{28}$ dan data sekunder. ${ }^{29}$

\section{Hasil Penelitian Dan Pembahasan}

\section{Pengumpulan dan Pendistribusian Zakat Produktif di Rumah Zakat Sumatera Utara}

Pengumpulan dana zakat, infak dan sedekah dilakukan dengan berbagai sarana, seperti auto zakat (Infaq Card), jemput zakat, teledonation, zakat via gesek zakat, zakat via online banking, zakat via ATM, zakat via visiting counter. Pada tahun 2016 Rumah Zakat Sumatera Utara berhasil menghimpun dana sebesar Rp 5,4 miliar. 80 persen dana itu berasal dari Kota Medan, dan sisanya Binjai, Langkat, Deli Serdang, Serdang Bedagai dan wilayah Sumatera Utara lainnya.

Pengelolaan semua dana zakat yang masuk disalurkan pada empat program utama. Program itu di antaranya Senyum Juara (pendidikan), Senyum Sehat (kesehatan), Senyum Mandiri (kesejahteraan ekonomi) dan Senyum Lestari (kebencanaan dan lingkungan). Keempat program utama ini disebut juga gerakan Big Smile Indonesia, gerakan ini merupakan bentuk ikhtiar Rumah Zakat menjadi mitra pemerintah Indonesia untuk mengurangi angka kemiskinan dan meningkatkan Indeks Pembangunan Manusia (IPM).

Dana Rp 5,4 miliar ini digunakan untuk empat program Senyum Rumah Zakat kepada 68.523 penerima. Dari jumlah 68.523 tersebut, total penerima manfaat terbanyak berasal dari Senyum Sehat sebesar 67.022 orang. Sektor ini menyerap paling banyak karena sebagian besar masyarakat kurang mampu masih sangat memerlukan layanan kesehatan layak. Penerima manfaat dari Senyum Juara formal sebanyak 164 orang dan non formal 1074 orang yang terdiri dari siswa SD, SMP dan SMA. Beberapa program beasiswa membagikan Rp 40 juta hingga Rp 50 juta per bulan, dan ada juga sedikit mahasiswa yang termasuk sebagai penerima manfaat dalam kategori ini. Kemudian, sebanyak 70 kepala keluarga pelaku usaha kecil mikro menerima dana manfaat Senyum Mandiri. Yang terletak di Kecamatan Medan Denai, Medan Helvetia (Kelurahan Dwikora) dan Medan Tembung. Para pengusaha kecil ini mendapatkan pendampingan penuh dari fasilitator RZ setiap harinya. Tujuannya untuk penguatan merk, manajemen bisnis dan lain sebagainya. Sisa penerima dana manfaat yang terakhir 
dari Senyum Lestari sebanyak 193 orang. Ini terdiri dari empat program pokok, yaitu masyarakat siaga bencana, kampus relawan, pelajar siaga bencana dan event. $^{30}$

Dalam pemberian bantuan modal tidak langsung diberikan oleh pihak Rumah Zakat. Proses pemilihan mustahik yang berhak menerima bantuan modal dilakukan analisa oleh pihak Rumah Zakat. Pada awalnya mustahik mengajukan permohonan bantuan modal kepada pihak Rumah Zakat, kemudian pihak Rumah Zakat melakukan penyeleksian dan melakukan analisa mustahik mana saja yang berhak menerima bantuan modal. Mustahik terpilih diwajibkan mengisi formulir.

Ada beberapa persyaratan dan prosedur yang harus mustahik lengkapi yaitu (1) mengisi formulir, (2) masuk kategori asnaf (3) mempunyai usaha minimal 6 bulan (4) maksimal umur 40 tahun (5) dari keluarga miskin (dibuktikan dengan surat keterangan miskin dari lurah atau BKM kemasjidan setempat) dan (6) bersedia mengikuti peraturan yang ditetapkan oleh Rumah Zakat serta bersedia mengikuti pembinaan.

Setelah memenuhi semua kriteria pihak Rumah Zakat akan melakukan survey ke lokasi usaha. Setelah ditetapkan mustahik yang berhak menerima bantuan modal maka dilakukan monitoring usaha, agar mustahik dapat dilihat perkembangan usahanya. Monitoring dilakukan dengan adanya kunjungan dari pihak Rumah Zakat kepada mustahik.

Rumah Zakat Sumatera Utara memiliki berbagai program dalam melakukan pendistribusian dana zakat yang telah dihimpun. Salah satu program yang khusus menangani pemberdayaan ekonomi mustahik adalah Program Senyum Mandiri. Program senyum mandiri merupakan implementasi distribusi zakat produktif, sehingga memberikan dampak jangka panjang bagi para mustahik, yang dilaksanakan oleh Rumah Zakat Sumatera Utara dalam mengembangkan ekonomi mustahik, dimana dengan program tersebut diharapkan para mustahik bisa tersenyum dan mandiri dalam menjalankan kehidupannya serta berkecukupan untuk memenuhi kebutuhannya.

Model pendistribusian dana zakat produktif kepada mustahik pada program senyum mandiri ialah pendistribusian dalam bentuk pemberian dana zakat berupa dana yang bersifat hibah atau bantuan murni kepada mustahik yang kekurangan dana untuk modal dan sarana usaha, sehingga bagi mustahik tidak ada tuntutan 
harus mengembalikan dana tersebut, karena bantuan ini sifatnya bukan pinjaman akan tetapi sudah menjadi hak milik dari mustahik.

Pada Rumah Zakat penyaluran dana zakat produktif dalam bentuk dana hibah yang diberikan kepada mustahik yang bersumber dari dana zakat yang ada di Rumah Zakat dan digunakan untuk modal usaha. Dana hibah yang diberikan Rumah Zakat ini karena bersifat dana bantuan jadi siapapun yang mendapatkan dana hibah tidak berkewajiban untuk mengembalikan dana tersebut. Mustahik yang mendapatkan dana hibah harus memanfaatkan dana tersebut untuk kebaikan dan digunakan untuk usaha yang produktif.

Pelaksanaan distribusi zakat produktif di Rumah Zakat Sumatera Utara melalui program senyum mandiri, yaitu melakukan pengembangan usaha mustahik dengan kegiatan-kegiatan yang meliputi edukasi kewirausahaan, pemberian sarana usaha, Good Manufacturing Practice (GMP), legalitas, penguatan produk dan pemasaran. Namun dalam pengaplikasian kegiatan tersebut dilakukan secara bertahap dan juga melihat kebutuhan dari anggota program senyum mandiri dalam mengembangkan usahanya, untuk kategori Program Senyum Mandiri ini hanya terdapat bagi asnaf miskin saja, karena untuk bisa diproduktifkan harus mencukupi kebutuhan dasar asnaf, sebagaimana aturan dari Undang-Undang No 23 tahun 2011 tentang pengelolaan zakat.

Dari wawancara dengan Bapak Rozali ${ }^{31}$ diperoleh langkah-langkah yang dilakukan oleh Rumah Zakat dalam mengembangkan usaha mustahik sebagai berikut:

a) Pendataan dan penseleksian mustahik

Pendataan yang dilakukan pada mulanya hanya terbatas pada mustahik yang mengajukan permohonan kepada Rumah Zakat, pendataan dilakukan melalui wawancara dengan para calon mustahik satu persatu.

b) Analisis kelayakan bisnis

Pendataan selanjutnya adalah tim program melakukan survey terhadap usaha, tempat tinggal, dan kegiatan sehari-harinya, setelah itu tim program akan menyeleksi mereka yang layak dan tidak layak menjadi mustahik binaan Rumah Zakat. 
c) Penyaluran modal usaha

Penyaluran dana zakat produktif yang dilakukan oleh Rumah Zakat melalui program Senyum Mandiri memprioritaskan mustahik yang telah memiliki usaha mikro minimal 6 bulan.

Pemberdayaan ekonomi yang ada di Rumah Zakat terdapat 13 mustahik yang mendapat bantuan. Rumah Zakat lebih memfokuskan pada kualitas dari pada banyaknya kuantitas sehingga mudah untuk dibina.

Tabel 1 Daftar Mustahik yang Mendapatkan Dana Zakat Produktif

\begin{tabular}{|c|c|c|c|}
\hline No & Nama & Jenis Usaha & Alamat lengkap \\
\hline 1 & $\begin{array}{l}\text { Johan } \\
\text { Wahyudi }\end{array}$ & $\begin{array}{r}\text { Printing, cetak } \\
\text { foto }\end{array}$ & $\begin{array}{r}\text { Jl. Budi Luhur Gg. Mesjid Lk. I No. 44- } \\
\text { D Kel. Dwikora Kec. Medan Helvetia } \\
\text { Medan }\end{array}$ \\
\hline 2 & Sudarto & Bakso bakar & $\begin{array}{r}\text { Jl. Bakti Luhur Gg. Tirto Kel. Dwi Kora } \\
\text { Kec. Medan Helvetia Medan }\end{array}$ \\
\hline 3 & Sudil & $\begin{array}{r}\text { Lontong Sayur, } \\
\text { nasi uduk }\end{array}$ & $\begin{array}{l}\text { J1. Setia Luhur Gg. Keluarga Kel. Dwi } \\
\text { Kora Kec. Medan Helvetia Medan }\end{array}$ \\
\hline 4 & Palupi & $\begin{array}{r}\text { Mie Sop - Aneka } \\
\text { Gorengan }\end{array}$ & $\begin{array}{r}\text { Jl. Setia Luhur Lk. VI No. } 93 \text { Kelurahan } \\
\text { Dwi Kora Medan }\end{array}$ \\
\hline 5 & 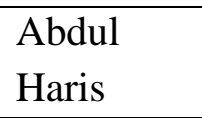 & Rujak & $\begin{array}{r}\text { Jl. Setia Luhur Gg. Hidayah Lk. XI Kel. } \\
\text { Dwi Kora Medan }\end{array}$ \\
\hline 6 & Elia! & $\begin{array}{r}\text { Mie Pecal, } \\
\text { bumbu pecal } \\
\text { kemasan }\end{array}$ & $\begin{array}{r}\text { Jln. Bakti Luhur Gg. Banteng Kel. } \\
\text { Dwikora Medan }\end{array}$ \\
\hline 7 & ASI1 & $\begin{array}{r}\text { Nasi goreng } \\
\mathrm{gc}\end{array}$ & $\begin{array}{r}\text { Jl. Budi Luhur No. } 54 \text { Lk. I Kel. } \\
\text { Dwikora Medan }\end{array}$ \\
\hline 8 & $\begin{array}{l}\text { Benny } \\
\text { Hidayat }\end{array}$ & $\begin{array}{r}\text { Telur gulung, } \\
\text { Otak-otak Ikan }\end{array}$ & $\begin{array}{r}\text { Jln. Amal Luhur Gg. Rejo Kel. Dwikora } \\
\text { Medan }\end{array}$ \\
\hline 9 & Sri & Rujak buah & $\begin{array}{r}\text { Jl. Budi Luhur No. 111 Kel. Dwikora } \\
\text { Medan }\end{array}$ \\
\hline 10 & $\begin{array}{l}\text { Eka } \\
\text { Wahyuni }\end{array}$ & $\begin{array}{r}\text { Bubur kacang } \\
\text { hijau, bubur } \\
\text { sumsum }\end{array}$ & $\begin{array}{r}\text { J1. Setia Luhur Gg. Keluarga No. } 171 \\
\text { Lk. VI Kel. Dwikora }\end{array}$ \\
\hline 11 & Nurbayani & Rujak buah & $\begin{array}{r}\text { Jl. Budi Luhur No. } 111 \text { Kel. Dwikora } \\
\text { Medan }\end{array}$ \\
\hline 12 & ji & $\begin{array}{r}\text { Mie sop, mie } \\
\text { goreng }\end{array}$ & $\begin{array}{r}\text { Jl. Setia Luhur Gg. Keluarga No. } 171 \\
\text { Lk. VI Kel. Dwikora }\end{array}$ \\
\hline 13 & ndi & Baks & $\begin{array}{r}\text { Jl. Bakti Luhur Gg. Jafar Kel. Dwikora } \\
\text { Medan }\end{array}$ \\
\hline
\end{tabular}

Sumber: Rumah Zakat Sumatera Utara 
Dari tabel diatas dapat disimpulkan bahwa ada bermacam-macam kategori yang menjadi usaha anggota binaan program senyum mandiri di kelurahan Dwikora. Jumlah mustahik yang ada di Rumah Zakat ada 13 mustahik yang mana mustahik tersebut benar-benar dibina dan diarahkan sehingga bisa menjadi sukses.

Pendistribusian dana zakat produktif diberikan kepada para mustahik dalam bentuk modal usaha dan sarana usaha yang mempunyai usaha minimal 6 bulan akan tetapi mereka kekurangan dana untuk usaha mereka.

Dana zakat produktif yang diterima oleh mustahik setiap bulannya berbeda, tergantung dari kebutuhan mustahik. Pemberian dana zakat ini sifatnya bergantian diutamakan kepada yang lebih membutuhkan.

Model pemberdayaan yang dilakukan oleh Rumah Zakat meliputi 5 hal berikut: 1) Pendampingan yaitu mendampingi mustahik sampai dia sukses dan bertransformasi menjadi muzaki. 2) Pembinaan yaitu membina mustahik dengan menghadirkan pemateri orang sukses dalam wirausaha agar para mustahik bisa termotivasi dalam menjalankan usahanya. 3) pelatihan yaitu dengan membekali keterampilan kepada mustahik dan masyarakat sekitar daerah binaan agar mampu mandiri dalam usahanya. 4) pemantauan (monitoring) yaitu untuk mengetahui perkembangan mustahik baik usahanya, modal dan kebutuhan selanjutnya dari mustahik dalam usahanya. dan terakhir pendampingan agama yaitu agar para mustahik semakin meningkatkan kualitas keimanan dan keislamannya.

Rumah Zakat Sumatera Utara juga melakukan evaluasi di akhir tahun untuk para mustahik, ini meliputi: sikap dan perilaku, take home pay, perilaku hidup sehat dan perilaku peduli dengan kesehatan. Dari proses evaluasi ini akan diketahui sejauh mana perkembangan usaha dari anggota program senyum mandiri. Selain itu evaluasi yang dilakukan juga menentukan tindakan yang selanjutnya diambil dalam mengembangkan usaha anggota program senyum mandiri.

\section{Efektivitas Distribusi Zakat Produktif dalam Meningkatkan Kesejahteraan Mustahik Tahun 2016}

Pendistribusian zakat produktif yang dilakukan oleh Rumah Zakat cabang Sumatera Utara melalui program senyum mandiri di Kelurahan Dwikora Kecamatan Medan Helvetia sejak 2016 terdapat 13 orang mustahik yang memiliki berbagai macam jenis usaha. Dari hasil wawancara dengan mustahik yang telah menerima bantuan dana zakat produktif dari Rumah Zakat dan melihat 
kesejahteraan para mustahik setelah mendapatkan bantuan dana zakat produktif, penulis menganalisa sesuai dengan kondisi mustahik.

Tabel 2 Kondisi Pendapatan Mustahik Per Tahun Sebelum dan Setelah Mendapat Dana Bantuan Zakat Produktif

\begin{tabular}{|c|c|c|c|c|c|c|}
\hline \multirow{3}{*}{ No } & \multirow{3}{*}{ Nama } & \multirow{2}{*}{\multicolumn{2}{|c|}{$\begin{array}{c}\text { Pendapatan pertahun } \\
\text { (dalam jutaan rupiah) }\end{array}$}} & \multirow{2}{*}{\multicolumn{3}{|c|}{$\begin{array}{c}\text { Kesejahteraan mustahik } \\
\text { Kondisi pendapatan } \\
\end{array}$}} \\
\hline & & & & & & \\
\hline & & Sebelum & Setelah & Tetap & Membaik & maju \\
\hline 1 & $\begin{array}{l}\text { Johan } \\
\text { Wahyudi }\end{array}$ & 28.8 & 36 & & $\sqrt{ }$ & \\
\hline 2 & $\begin{array}{l}\text { Endang } \\
\text { Palupi }\end{array}$ & 46.8 & 57.6 & & & $\sqrt{ }$ \\
\hline 3 & Eka Wahyuni & 36 & 36 & $\sqrt{ }$ & & \\
\hline 4 & Eliana & 36 & 36 & $\sqrt{ }$ & & \\
\hline 5 & Sudirman & 36 & 36 & $\sqrt{ }$ & & \\
\hline 6 & Cilia Asfika & 43.2 & 57.6 & & & $\sqrt{ }$ \\
\hline 7 & Abdul Haris & 45 & 59.4 & & & $\sqrt{ }$ \\
\hline 8 & Ruji Sutinah & 36 & 36 & $\sqrt{ }$ & & \\
\hline 9 & Sudarto & 36 & 90 & & & $\sqrt{ }$ \\
\hline 10 & Syafriandi & 36 & 46 & & $\sqrt{ }$ & \\
\hline 11 & $\begin{array}{l}\text { Benny } \\
\text { Hidayat }\end{array}$ & 28.8 & 43.2 & & $\sqrt{ }$ & \\
\hline 12 & Sri Wahyuni & 28.8 & 32.4 & & $\sqrt{ }$ & \\
\hline 13 & Nurbayani & 36 & 36 & $\sqrt{ }$ & & \\
\hline
\end{tabular}

Pada tabel 2 menunjukkan bahwa terdapat 5 dari 13 mustahik yang pendapatannya tetap setelah diberikan dana zakat produktif, mustahik tersebut adalah Eka Wahyuni, Eliana, Sudirman, Ruji Sutinah dan Nurbayani. Hal ini dikarenakan stok dari penjualannya masih sama dengan saat sebelum dan sesudah mendapatkan dana zakat, meskipun modalnya banyak, tetapi stok untuk penjualannya terbatas. Sedangkan 4 dari 13 mustahik, yaitu Johan Wahyudi, Syafriandi, Benny Hidayat dan Sri Wahyuni pendapatannya membaik dan terakhir 4 dari 13 mustahik lainnya ialah Endang Palupi, Cilia Asfika, Abdul Haris dan Sudarto pendapatannya mengalami kemajuan. Sebagian besar peningkatan pendapatan mustahik disebabkan oleh menambahnya variasi, kuantitas dan kualitas barang dagangan karena adanya tambahan modal dan alat bantu untuk usaha. 
Untuk mengetahui tingkat efektivitas sebuah pengaruh, penulis membagi ukuran efektivitas dalam dua bentuk sebagai berikut:

\section{a. Efektivitas minimal}

Efektivitas minimal ini ialah dengan melihat peningkatan dari pendapatan mustahik setelah mendapatkan dana zakat produktif apabila mustahik mengalami peningkatan pendapatan setelah mendapatkan dana zakat produktif, maka ia telah mencapai efektivitas minimal. Berikut tabel jumlah pendapatan mustahik pertahun setelah dan sebelum menerima dana zakat produktif.

Tabel 3 Jumlah Pendapatan Mustahik Per Tahun Setelah dan Sebelum Menerima Dana Zakat Produktif

\begin{tabular}{|c|c|c|c|c|c|}
\hline \multirow{2}{*}{ No } & \multirow{2}{*}{ Nama } & \multicolumn{2}{|c|}{$\begin{array}{l}\text { Pendapatan pertahun } \\
\text { (dalam jutaan rupiah) }\end{array}$} & \multicolumn{2}{|c|}{ Kategori } \\
\hline & & Sebelum & Setelah & Tetap & Meningkat \\
\hline 1 & $\begin{array}{l}\text { Johan } \\
\text { Wahyudi }\end{array}$ & 28,8 & 36 & & $\sqrt{ }$ \\
\hline 2 & Endang Palupi & 46,8 & 57,6 & & $\sqrt{ }$ \\
\hline 3 & Eka Wahyuni & 36 & 36 & $\sqrt{ }$ & \\
\hline 4 & Eliana & 36 & 36 & $\sqrt{ }$ & \\
\hline 5 & Sudirman & 36 & 36 & $\sqrt{ }$ & \\
\hline 6 & Cilia Asfika & 43,2 & 57,6 & & $\sqrt{ }$ \\
\hline 7 & Abdul Haris & 45 & 59,4 & & $\sqrt{ }$ \\
\hline 8 & Ruji Sutinah & 36 & 36 & $\sqrt{ }$ & \\
\hline 9 & Sudarto & 36 & 90 & & $\sqrt{ }$ \\
\hline 10 & Syafriandi & 36 & 46 & & $\sqrt{ }$ \\
\hline 11 & Benny Hidayat & 28 & 43,2 & & $\sqrt{ }$ \\
\hline 12 & Sri Wahyuni & 28,8 & 32,4 & & $\sqrt{ }$ \\
\hline 13 & Nurbayani & 36 & 36 & $\sqrt{ }$ & \\
\hline
\end{tabular}

Dari tabel diatas dapat dilihat bahwa dari 13 mustahik yang mendapatkan dana zakat produktif, yang mengalami peningkatan pendapatan ialah 8 orang, yaitu Johan Wahyudi, Endang Palupi, Cilia Asfika, Abdul Haris, Sudarto, Syafriandi, Benny Hidayat dan Sri Wahyuni. Dari hasil analisis data pendapatan mustahik maka dapat disimpulkan bahwa para mustahik telah mencapai efektivitas minimal.

b. Efektivitas maksimal

Efektivitas maksimal ialah tingkat pendapatan mustahik yang mencapai tingkat muzaki. Untuk ukuran mencapai tingkat muzaki, hal ini sesuai dengan 
yang ditetapkan oleh Rumah Zakat yaitu untuk mencapai tingkat muzaki maka pendapatan pertahun harus mencapai 85 gram emas.

Harga emas per gram $=650.000$

$85 \times 650.000=55.250 .000$

Maka, jika mustahik mendapatkan pendapatan pertahun sebanyak 55.250.000 maka mustahik sudah mampu mencapai taraf muzaki.

Untuk mengetahui mustahik yang telah mencapai tingkat muzaki, maka dari 8 orang mustahik yang telah mencapai efektivitas maksimal akan dilihat kembali dari tabel berikut:

Tabel 4 Jumlah Pendapatan Mustahik yang telah Mencapai Efektivitas Maksimal

\begin{tabular}{|c|l|c|c|}
\hline No & Nama & $\begin{array}{c}\text { Pendapatan per tahun } \\
\text { (dalam jutaan rupiah) }\end{array}$ & Muzaki \\
\hline 1 & Johan Wahyudi & 36 & $\sqrt{ }$ \\
\hline 2 & Endang Palupi & 57.6 & $\sqrt{ }$ \\
\hline 3 & Cilia Asfika & 57.6 & $\sqrt{ }$ \\
\hline 4 & Abdul Haris & 59.4 & $\sqrt{ }$ \\
\hline 5 & Sudarto & 90 & \\
\hline 6 & Syafriandi & 46 & \\
\hline 7 & Benny Hidayat & 43.2 & \\
\hline 8 & Sri Wahyuni & 32.4 & \\
\hline
\end{tabular}

Dari tabel 4 di atas maka dapat disimpulkan bahwa empat dari delapan orang mustahik pendapatannya telah mencapai taraf muzaki, maka dengan demikian distribusi zakat produktif yang dilakukan oleh Rumah Zakat Sumatera Utara bisa dikatakan telah efektif, ini dibuktikan dengan sebagian anggota senyum mandiri binaan Rumah Zakat telah mencapai tujuan dari Rumah Zakat, yaitu memuzakikan mustahik. Dan disini yang telah menjadi muzaki ialah Ibu Endang Palupi, Ibu Cilia Asfika, Bapak Abdul Haris dan bapak Sudarto. Karena kembali ke tujuan dari Rumah Zakat sendiri yang menjadi indikator efektivitas sebuah lembaga ialah tercapainya tujuan utama dari lembaga tersebut. Dan tujuan dari Rumah Zakat dalam mendistribusikan zakat produktif kepada mustahik ialah agar para mustahik mampu menjadi mandiri secara ekonomi dan mecapai taraf muzaki, agar kehidupannya menjadi sejahtera. Dan tujuan dari Rumah Zakat ini telah tercapai melalui empat orang mustahik tersebut diatas yang telah menjadi muzaki. 
Bantuan zakat produktif yang diberikan oleh Rumah Zakat Sumatera Utara melalui program senyum mandiri kepada mustahik di daerah binaan Kelurahan Dwikora Kecamatan Medan Helvetia dapat meningkatkan dua faktor kesejahteraan mustahik. Sehingga zakat produktif yang didistribusikan oleh Rumah Zakat Sumatera Utara dinilai sudah cukup efektif dalam meningkatkan kesejahteraan mustahik.

Akan tetapi dalam hal ini penulis menganalisa bantuan zakat produktif yang diberikan oleh Rumah Zakat Sumatera Utara tidak banyak sehingga peluang maju untuk mustahik kurang maksimal, karena masih ada mustahik yang kondisi pendapatannya masih tetap.

\section{Kesimpulan}

Dari analisis dan pembahasan dapat ditarik kesimpulan tentang efektivitas distribusi zakat produktif pada Rumah Zakat Sumatera Utara. Kesimpulan tersebut sebagai berikut:

1. Dalam mendistribusikan dana zakat produktif, Rumah Zakat berpedoman pada Syariat Islam dan Undang-undang No. 23 tahun 2011 tentang pengelolaan zakat. Rumah Zakat Sumatera Utara memiliki berbagai program dalam melakukan pendistribusian dana zakat yang telah dihimpun. Salah satu program yang khusus menangani pemberdayaan ekonomi mustahik adalah "Program Senyum Mandiri". Program Senyum Mandiri merupakan implementasi distribusi zakat produktif, sehingga memberikan dampak jangka panjang bagi mustahik. Dana zakat produktif yang disalurkan dalam program senyum mandiri berbentuk bantuan sarana usaha, bantuan modal usaha dan pemberdayaan. Dengan bantuan tersebut diharapkan mustahik dapat mengembangkan usaha yang dimilikinya dan pendapatan mustahik meningkat, sehingga kesejahteraan mustahik akan meningkat. Bentuk dana zakat produktif yang di salurkan oleh Rumah Zakat ialah bentuk dana hibah, sehingga mustahik tidak perlu mengembalikan dana tersebut, karena dana tersebut memang sudah hak untuk dimiliki seutuhnya oleh mustahik, akan tetapi mustahik harus mengikuti aturan dari Rumah Zakat dalam hal ini ialah pembinaan dan pemberdayaan. Hal ini telah sesuai dengan Undang-undang No. 23 tahun 2011 tentang pengelolaan zakat. 
2. Distribusi zakat produktif yang diberikan oleh Rumah Zakat Sumatera Utara melalui "Program Senyum Mandiri" kepada mustahik di daerah binaan Kelurahan Dwikora Kecamatan Medan Helvetia dapat meningkatkan dua faktor kesejahteraan mustahik. Sehingga zakat produktif yang didistribusikan oleh Rumah Zakat Sumatera Utara dinilai sudah efektif dalam meningkatkan kesejahteraan mustahik, ini dibuktikan dengan meningkatnya pendapatan delapan dari tiga belas orang mustahik, dan hanya lima orang yang pendapatannya tetap. dan empat dari delapan orang yang pendapatannya meningkat telah mencapai tingkat muzaki.

Berdasarkan kesimpulan di atas, maka saran-saran yang dapat diberikan adalah Rumah Zakat Sumatera Utara supaya terus memperbanyak jaringan donatur-donatur dan mitra kerja agar dapat memperluas dalam pemberian bantuan untuk mustahik, baik untuk pengembangan kegiatan ekonomi maupun maupun lainnya. Dan perlu adanya penelitian lebih lanjut untuk kajian-kajian yang lebih mendalam secara terus menerus tentang pendayagunaan dana zakat yang digunakan untuk pemberdayaan mustahik, sebab dengan adanya program kegiatan ekonomi dan pelatihan-pelatihan skill untuk mustahik zakat maka akan mengurangi tingkat pengangguran di Indonesia.

\section{Catatan}

${ }^{1}$ Lihat: Surat At-Taubah ayat 60

2 Agus Hidayatullah, et.al., AlJamil Al-Qur'an Tajwid Warna, Terjemah Per Kata, Terjemah Inggris (Bekasi: Cipta Bagus Segara, 2012), h. 203. (Tanda Tashih kode: VII/U/0.10/II/2012, tanggal 6 Februari 2012).

${ }^{3}$ Peraturan perundang-undangan Republik Indonesia Nomor 23 Tahun 2011 tentang pengelolaan zakat, h. 6

${ }^{4}$ M. Arif Mufraini, Akuntansi dan Manajemen Zakat: Mengkomunikasikan Kesadaran dan Membangun Jaringan (Jakarta: Kencana Prenada Media Group, 2006), h. 154

${ }^{5}$ www. rumahzakat.org

${ }^{6}$ Didin Hafidhuddin, Mutiara Dakwah: Mengupas konsep Islam tentang Ilmu, harta, Zakat dan Ekonomi Syariah (Jakarta: Kuwais, 2006), h. 206.

${ }^{7}$ Sulkan Yasin dan Sunarto Hapsoyo, Kamus Besar Bahasa Indonesia, Praktis, Populer dan Kosa Kata Baru, (Surabaya: Mekar, 2008), h. 132.

${ }^{8}$ Harbani Pasolong, Teori Administrasi Publik, (Bandung: Alfabeta, 2007), h. 4. 109.

9 Agung Kurniawan, Transformasi Pelayanan Publik, (Yogyakarta: Pembaruan, 2005), h. 120 Cipta, 2001)

${ }^{10}$ James L. Gibson, et. al., Organisasi, Terj. Agus Dharma, (Jakarta: Erlangga, 2001) h.

11 Sondang P. Siagian, Kiat Meningkatkan Produktifitas Kerja, (Jakarta: PT. Rineka

${ }_{12}^{12}$ Martani dan Lubis, Teori Organisasi, (Bandung: Ghalia Indonesia, 1987), h. 55.

${ }^{13}$ Pusat Bahasa Departemen Pendidikan Nasional, Kamus Bahasa Indonesia, (Jakarta: Balai Pustaka, 2003)

${ }^{14}$ Yūsuf al-Qarāḍāwi, Hukm Az-Zakah, terj. Salman Harun dkk, Hukum Zakat (Bandung: Mizan, 1996), h. 510 
${ }^{15}$ Didin Hafidhuddin, Zakat dan Peningkatan Kesejahteraan (Upaya Memahami Kembali Makna Dan Hakikat Zakat) dalam Mimbar Agama dan Budaya, (Jakarta: Penerbit UIN Syarif Hidayatullah, 2002), h.264

${ }^{16}$ Muhammad Daud Ali, Sistem Ekonomi Islam; Zakat dan Wakaf (Jakarta: Universitas Indonesia, 1988), h. 62-63

${ }^{17}$ Ibnu Manzūr, Lisān al- 'Arab (Beirut: Dār aṣ-Ṣādir, t.t.), jilid 14, h. 358

18 Muhammad Ibn Aḥmad al-Khațib asy-Syarbini asy-Syāfi‘i, Mugniy al-Muḥtāj Ilā Ma 'rifah Alfāz al-Minhāj (Kairo: Dār at-Taufiqiyyah, 1994), jilid II, h. 68

${ }^{19}$ Saparuddin Siregar, Akuntansi zakat dan infak/sedekah sesuai PSAK 109, (Medan: Wal Ashri Publishing, 2013), h. 293

${ }^{20}$ Joyce M. Hawkins, Kamus Dwi Bahasa Inggris-Indonesia, Indonesia-Inggris, (Exford: Erlangga, 1996), h. 267

${ }^{21}$ Tim Penyusun Kamus Pusat Pembinaan dan Pengembangan Bahasa Departemen Pendidikan dan Kebudayaan, Kamus Besar Bahasa Indonesia, (Jakarta: Pustaka Firdaus, 1990). h. 209

${ }^{22}$ Save M. Dagun, Kamus Besar Ilmu Pengetahuan, (Jakarta: LPKN, 2000), h. 893

${ }^{23}$ Ibid., h. 78-80

${ }^{24}$ M. Arif Mufraini, Akuntansi dan Manajemen Zakat: Mengkomunikasikan Kesadaran dan Membangun Jaringan (Jakarta: Kencana Prenada Media Group, 2006), h. 106-111

${ }^{25}$ Lexy J. Moleong, Metodologi Penelitian Kualitatif (Bandung: PT Remaja Rosdakarya, cet. 31,2013$)$, h. 6 .

${ }^{26}$ Sugiono, Metode Penelitian Kuantitatif, Kualitatif dan R\&D (Bandung: CV. Alfabeta, 2009), h. 8

${ }^{27}$ Burhan Bungin, Metodologi Penelitian Kualitatif (Jakarta: PT Grafindo Persada, 2001), h. 234

${ }^{28}$ Pengurus Rumah Zakat yang bertanggung jawab pada program senyum mandiri, penerima dana zakat produktif Rumah Zakat Sumatera Utara serta pihak-pihak lain yang terkait, dimaksudkan untuk mendengar keterangan dari mereka dengan fakta-fakta, kejadian-kejadian yang mereka alami dan mereka ketahui.

${ }^{29}$ Laporan penelitian, jurnal, laporan tahunan Rumah Zakat Sumatera Utara, literaturliteratur hukum Islam dan ekonomi Islam yang relevan dengan penelitian dan lain sebagainya.

${ }^{30}$ www.rumahzakat.org

${ }^{31}$ Rozali, Fasilitator Program Senyum Mandiri Desa Berdaya Medan Dwikora binaan Rumah Zakat Sumatera Utara, Wawancara di Kantor Cabang Rumah Zakat Sumatera Utara, tanggal 16 November 2018

\section{Daftar Pustaka}

Ali, Muhammad Daud. 1988. Sistem Ekonomi Islam; Zakat dan Wakaf. Jakarta: Universitas Indonesia.

al-Qarāọāwi, Yūsuf. 1996. Hukm Az-Zakah, terj. Salman Harun dkk, Hukum Zakat. Bandung: Mizan.

Bungin, Burhan. 2001. Metodologi Penelitian Kualitatif. Jakarta: Grafindo Persada.

Dagun, Save M. 2000. Kamus Besar Ilmu Pengetahuan. Jakarta: LPKN.

Gibson, James L et. al. 2001. Organisasi, Terj. Agus Dharma, Jakarta: Erlangga. Hafidhuddin, Didin. 2006. Mutiara Dakwah: Mengupas konsep Islam tentang Ilmu, harta, Zakat dan Ekonomi Syariah. Jakarta: Kuwais. 
2002. Zakat dan Peningkatan Kesejahteraan (Upaya Memahami

Kembali Makna Dan Hakikat Zakat) dalam Mimbar Agama dan Budaya. Jakarta: Penerbit UIN Syarif Hidayatullah.

Hawkins, Joyce. 1996. M. Kamus Dwi Bahasa Inggris-Indonesia, IndonesiaInggris. Exford: Erlangga.

Hidayatullah, Agus et.al. 2012. AlJamil Al-Qur'an Tajwid Warna, Terjemah Per Kata, Terjemah Inggris. Bekasi: Cipta Bagus Segara.

Kurniawan, Agung. 2005. Transformasi Pelayanan Publik. Yogyakarta: Pembaruan.

Manz̄ūr, Ibnu. Lisān al- 'Arab. Beirut: Dār aṣ-Șādir, t.t.

Martani dan Lubis. 1987. Teori Organisasi. Bandung: Ghalia Indonesia.

Moleong, Lexy J. 2013. Metodologi Penelitian Kualitatif. Bandung: Remaja Rosdakarya, cet. 31 .

Mufraini, M. Arif. 2006. Akuntansi dan Manajemen Zakat: Mengkomunikasikan Kesadaran dan Membangun Jaringan. Jakarta: Kencana Prenada Media Group.

Pasolong, Harbani. 2007. Teori Administrasi Publik. Bandung: Alfabeta.

Peraturan Perundang-undangan Republik Indonesia Nomor 23 Tahun 2011 tentang Pengelolaan Zakat.

Pusat Bahasa Departemen Pendidikan Nasional. 2003. Kamus Bahasa Indonesia. Jakarta: Balai Pustaka.

Rozali. Fasilitator Program Senyum Mandiri Desa Berdaya Medan Dwikora binaan Rumah Zakat Sumatera Utara, wawancara di Kantor Cabang Rumah Zakat Sumatera Utara, tanggal 16 November 2018.

Siagian, Sondang P. 2001. Kiat Meningkatkan Produktifitas Kerja. Jakarta: Rineka Cipta.

Siregar, Saparuddin. 2013. Akuntansi Zakat Dan Infak/Sedekah Sesuai PSAK 109, Medan: Wal Ashri Publishing.

Sugiono. 2009. Metode Penelitian Kuantitatif, Kualitatif dan R\&D. Bandung: CV. Alfabeta.

asy-Syāfi‘i. Muḥammad Ibn Aḥmad al-Khațib asy-Syarbini. 1994. Mugniy alMuhtāj Ilā Ma 'rifah Alfāz al-Minhāj. Kairo: Dār at-Taufiqiyyah. 
Tim Penyusun Kamus Pusat Pembinaan dan Pengembangan Bahasa Departemen Pendidikan dan Kebudayaan. 1990. Kamus Besar Bahasa Indonesia. Jakarta: Pustaka Firdaus.

www.rumahzakat.org

Yasin, Sulkan dan Sunarto Hapsoyo. 2008. Kamus Besar Bahasa Indonesia, Praktis, Populer dan Kosa Kata Baru. Surabaya: Mekar. 